\title{
The IRF Family Transcription Factors at the Interface of Innate and Adaptive Immune Responses
}

\author{
Hiroaki Ikushima, Hideo Negishi, and Tadatsugu Taniguchi \\ Department of Molecular Immunology, Institute of Industrial Science, The University of Tokyo, \\ Komaba 4-6-1, Meguro-ku, Tokyo 153-8505, Japan \\ Correspondence: tada@m.u-tokyo.ac.jp
}

\begin{abstract}
The interferon-regulatory factor (IRF) family, originally identified as transcriptional regulators of the type I interferon system, consists of nine members in mammals. A large number of studies have revealed the versatile and critical functions performed by this transcription factor family in immunity and other biological processes. Most notably, the advances in the study of signal transducing innate immune receptors have placed many IRF members as central mediators in the regulation of innate immune responses. In parallel, mechanistic studies have made it clearer that many IRFs exert their function either in cooperation or competition with other factors. In this article, we discuss current advances on the multipurpose and critical functions of IRFs in the regulation of innate immunity, particularly as they instruct adaptive immunity.
\end{abstract}

Prompt and tightly regulated cellular responses are central to host immunity. Such responses are coordinated by various intricate gene-regulatory networks, which mediate the rapid alterations in gene-expression programs within the cell. Such regulatory networks are controlled, in part, through the differential expression, posttranslational modification, and interconnection of transcription factors within a stimulated cell (Tjian and Maniatis 1994). The prototypical and most extensively studied transcription factor is nuclear factor- $\kappa \mathrm{B}(\mathrm{NF}-\kappa \mathrm{B})$. The importance of NF- $\kappa \mathrm{B}$ to gene-regulatory networks of immune responses, including the induction of the genes that encode interferons (IFNs) and proinflammatory cytokines, is well documented (Hayden and Ghosh 2008; Grivennikov et al. 2010). More recently, members of the interferon-regulatory factor (IRF) family of transcription factors have gained much attention for their regulation of the development and responses by immune cells because of their markedly diverse roles in regulating gene-expression networks within the immune system.

The mammalian IRF family consists of nine members: IRF1, IRF2, IRF3, IRF4 (also known as PIP, LSIRF, or ICSAT), IRF5, IRF6, IRF7, IRF8 (also known as ICSBP), and IRF9 (also known as ISGF3 $\gamma$ ) (Honda and Taniguchi 2006; Tamura et al. 2008). Each IRF protein contains a conserved amino-terminal DNA-binding domain, which recognizes DNA similar in sequence to the IFN-stimulated response element (ISRE; A/GNGAAANNGAAACT) (Darnell et al. 1994; Escalante et al. 1998; Fujii et al. 1999). Structural analyses of IRF3 revealed that the His40 residue within loop 1 (L1 loop) binds an upstream "AA" dinucleotide sequence, whereas the $\alpha$-helix 3 motif binds the downstream "GAAA" sequence (Panne et al. 2007) and, expectedly, these structures are well-conserved among IRFs.
The primary amino acid sequences of the carboxyterminal region, responsible for the regulation of IRFs' transcriptional activities, show more diversity within the family as compared to the amino-terminal region. This region is critical for specifying interactions between IRFs and with other transcription factors or cofactors, thereby conferring specific transcriptional activities and biological functions upon each IRF protein (Panne et al. 2007; Tamura et al. 2008; Chen and Royer 2010). Of note, two types of association modules have been identified within the carboxy-terminal region of IRFs: IRF-associated domains 1 and 2 (IAD1 and IAD2). IAD1 is conserved in all IRFs except for IRF1 and IRF2 (Sharf et al. 1997) and possesses structural similarities with the Mad-homology 2 (MH2) domain of the Smad family of transcription factors, which are crucial mediators of transforming growth factor- $\beta$ signaling (Ikushima and Miyazono 2010). IAD2 is shared by IRF1 and IRF2. The nature of the proteinprotein interaction dictated by these domains may determine whether the protein complex functions as a transcriptional activator or repressor, and specify the DNA sequences adjacent to ISRE to which the complex can bind (Honda and Taniguchi 2006).

With the discovery of signal-transducing pattern-recognition receptors (PRRs), used by the innate immune system to recognize pathogen-associated molecular patterns (PAMPs) (Janeway and Medzhitov 2002), IRFs have gained much attention as essential regulators for the activation of immune cells. Thus far, many classes of PRRs have been identified: Toll-like receptors (TLRs), retinoic acid-inducible gene-I (RIG-I)-like receptors (RLRs), NOD-like receptors (NLRs), C-type lectin receptors (CLRs), and other nucleic acid-sensing receptors (Blasius and Beutler 2010; Takeuchi and Akira 2010; Kawai and Akira 2011; Sancho and Reis e Sousa 2012). 
Depending on the nature of the pathogen and responding cell type, these recognition systems are differentially activated and elicit distinct cellular responses. In recent years, an extensive number of studies have revealed that IRFs function as important mediators of these responses. Also of note are critical roles of IRFs in the regulation of cellular responses linked to oncogenesis, for which we refer the reader to related review articles published elsewhere (Takaoka et al. 2008; Yanai et al. 2012).

\section{IRFS IN TYPE I IFN-INDUCING CYTOSOLIC PRR SIGNALING}

Numerous PRRs that can detect cytosolic nucleic acids have been identified and most of them can evoke type I IFN responses via activation of IRFs, particularly IRF3 and IRF7. Of note, these nucleic acids, as well as those that activate TLRs, all need to bind to HMGB family of proteins to exert their immunogenic activities (Yanai et al. 2009). The type I IFN-inducing cytosolic PRRs include the RLR family (comprising melanoma differentiation-associated gene 5 (MDA5) and RIG-I), stimulator of interferon genes (STING), DNA-dependent activator of IRFs (DAI), DEAD box polypeptide 41 (DDX41) interferon-gamma-inducible protein 16 (IFI16), RNA polymerase III (Pol III), and leucine rich repeat interacting protein 1 (LRRFIP1) (Fig. 1) (Fritz et al. 2006; Takeuchi and Akira 2010; Keating et al. 2011; Holm et al. 2013). The RLR proteins are composed of two amino-terminal caspase recruit domains (CARDs), a central DEAD box helicase/ATPase domain, and a carboxy-terminal regulatory domain (Yoneyama et al. 2005; Loo and Gale 2011). They are localized to the cytoplasm and are essential sensors for cytosolic RNAs (Andrejeva et al. 2004; Yoneyama et al. 2004; Kato et al. 2006). In general, double strand RNA (dsRNA) or 5'-triphosphate RNA derived from RNA viruses as well as $5^{\prime}$-triphosphate RNA from DNA viruses via Pol III are recognized by RLRs (Ablasser et al. 2009; Chiu et al. 2009). Specifically, RIG-I is critical for the recognition of shorter dsRNA $(<1 \mathrm{Kbp})$ and 5 '-triphosphate RNA, whereas MDA5 is critical for detection of longer dsRNA ( $>2 \mathrm{Kbp}$ ) (Kato et al. 2008; Takeuchi and Akira 2009). There is also evidence that RLRs contribute to the direct recognition of cytosolic DNA (Choi et al. 2009). The helicase domain is responsible for the detection of nucleic acids, whereas the CARD domain, exposed upon ligands binding to these receptors, triggers signaling cascades by interacting with the amino-terminal CARD-containing adaptor IFN- $\beta$ promoter stimulator 1 (IPS-1, also known as MAVS, CARDIF, or VISA) (Kawai and Akira 2006a). IPS-1 also contains a transmembrane region that is associated with the mitochondrial outer membrane, an event critical to triggering downstream signaling events. LGP2 is another, as yet poorly characterized, member of the RLR family that may play a role in sensitizing MDA5 for its activation by dsRNA (Childs et al. 2013).

The cytosolic DNA-sensing system also evokes protective and pathological immune responses (Paludan and Bowie 2013). The first discovered sensor, DAI (also known as ZBP1 or DLM1), activates cytosolic double strand DNA (dsDNA)-mediated type I IFN responses in a cell type-specific manner (Takaoka et al. 2007; Wang et al. 2008). Although DAI is necessary for cytosolic DNA-mediated type I IFN gene induction in mouse L929 cells, it is dispensable in other cells such as mouse embryonic fibroblasts (MEFs) or bone marrow-derived dendritic cells (Ishii et al. 2008; Wang et al. 2008). It is also reported that DAI is critical for cytomegalovirusinduced type I IFN gene expression in human fibroblasts (DeFilippis et al. 2010). Further study is required to fully determine cell type-specific roles of DAI in cytosolic DNA-mediated type I IFN responses.

Thereafter, an adaptor protein termed STING (also known as MITA, ERIS, or TMEM173) was identified (Ishikawa and Barber 2008; Zhong et al. 2008). Cells and mice lacking Sting show impaired IFN production in response to both DNA and RNA stimulation. However, recent data have suggested that STING is not the primary sensor of cytosolic DNA. Rather, DDX41, another cytosolic DNA sensor, functions as a direct receptor for cytosolic DNA (Parvatiyar et al. 2012). IFI16, a PYHIN protein, was also identified as a cytosolic DNA sensor that mediates the induction of IFN- $\beta$ (Unterholzner et al. 2010). DDX41 and IFI16 directly associate with IFNinducing viral DNA motifs, and then are recruited to STING to induce type I IFN gene expression. More recent reports have showed that cyclic guanosine monophosphate-adenosine monophosphate (cGAMP), which is produced in response to cytoplasmic DNA by cGAMP synthase (cGAS), binds to STING and then induces type I IFNs (Sun et al. 2013; Wu et al. 2013). Consistent with this, STING was shown to be critical for the recognition of cyclic diadenosine monophosphate (c-di-AMP) and cyclic diguanosine monophosphate (c-di-GMP) derived from bacteria, data which further indicate that STING is not a direct sensor of DNA but that of cyclic nucleotides (Burdette et al. 2011; Parvatiyar et al. 2012; Yin et al. 2012).

\section{IRFs in RLR Signaling}

RIG-I and MDA5 physically interact with IPS-1 via a CARD-CARD domain interaction following binding to cognate ligands. IPS-1 then relays signals to TANK-binding kinase 1 (TBK1) and inhibitor of NF-кB kinase $\epsilon$ $(\mathrm{IKK} \epsilon)$, which then phosphorylate IRF3 and IRF7 (Fitzgerald et al. 2003; Sharma et al. 2003). IRF3 is constitutively expressed and initially resides in the cytosol in a latent form, owing to its carboxy-terminal auto-inhibitory region. Following cytosolic RLR stimulation, the IPS-1activated TBK1 phosphorylates IRF3 at specific serine residues in the auto-inhibitory region, which allows IRF3 dimerization and nuclear translocation. As a result, the IRF3 dimer interacts with other transcription factors and coactivators CBP or p300 to form a holocomplex for transcriptional activation of type I IFNs and other target genes (Yoneyama et al. 1998).

Unlike IRF3, IRF7 is expressed at low levels in most cells and is strongly induced by type I IFN signaling via 


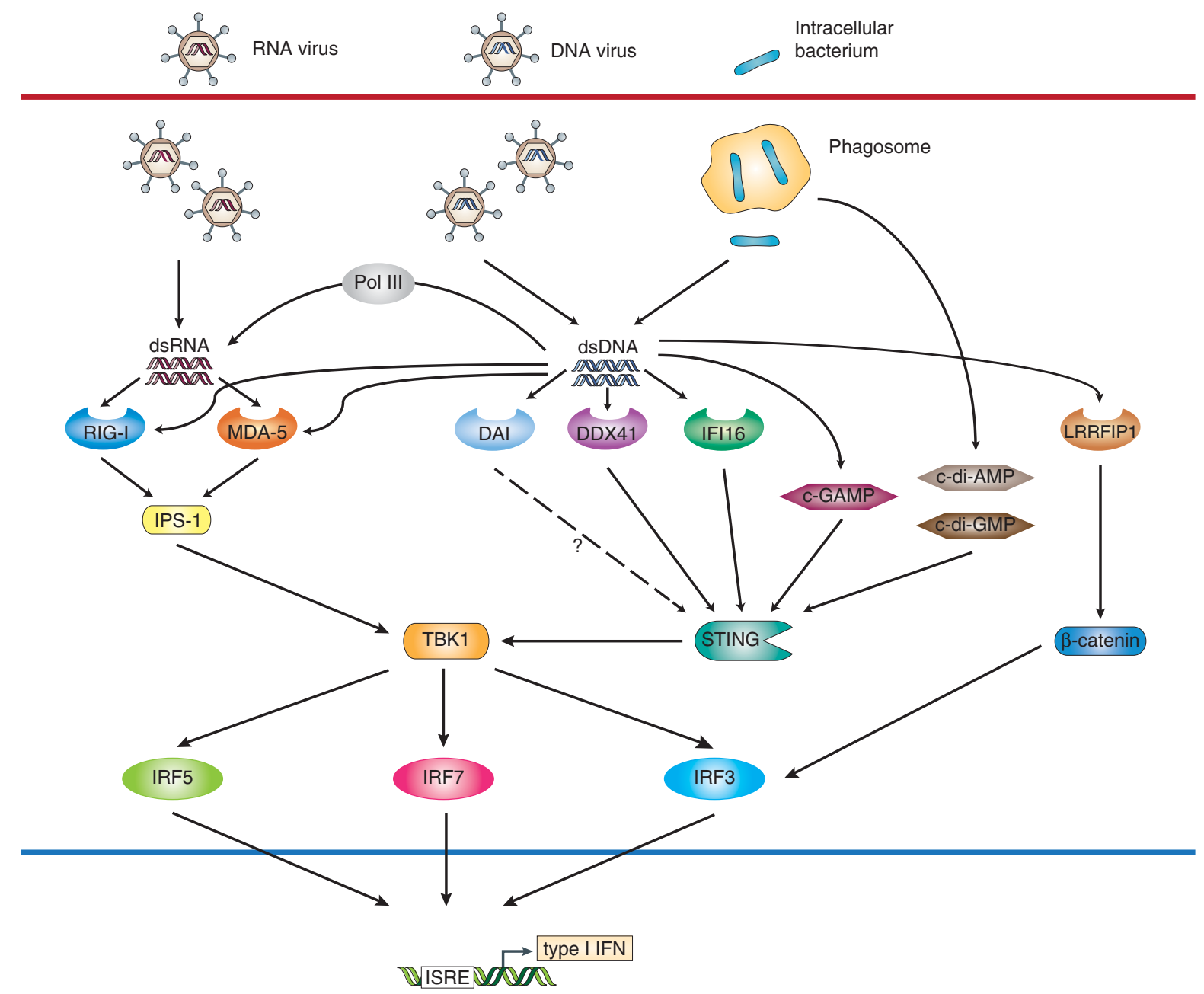

Figure 1. IRFs in cytosolic nucleic acid-induced type I IFN gene expression. The presence of double-strand RNA (dsRNA) or doublestrand DNA (dsDNA) in the cytosol triggers innate immune responses through the cytosolic pattern-recognition system. The interaction of dsRNA with RIG-I or MDA5 induces their interaction with the adaptor protein IPS-1. This interaction results in the activation of TBK1. The interaction of dsDNA with DDX41 and IFI16 allows STING to activate TBK1. Cyclic diadenosine monophosphate (cdi-AMP), cyclic diguanosine monophosphate (c-di-GMP), and cyclic guanosine monophosphate-adenosine monophosphate (cGAMP) act as direct ligands for STING to activate TBK1. IRF3, IRF5, and IRF7 are phosphorylated by TBK1, resulting in induction of type I IFNs. IRF3 also cooperates with $\beta$-catenin downstream from LRRFIP1.

binding of the transcription factor ISGF3 (a heterotrimeric complex consisting of Stat1, Stat2, and IRF9) to its gene promoter. IRF7 also resides in the cytosol of resting cells and, upon cytosolic RLR stimulation, undergoes serine phosphorylation of its carboxy-terminal region, allowing it to translocate into the nucleus and induce expression of type I IFN genes. Thus, the positive-feedback regulation of IRF7 comes into effect to achieve the full-blown induction of type I IFN genes during the later phases of the response (Honda and Taniguchi 2006; Chen and Royer 2010).

In addition to IRF3 and IRF7, IRF5 is also involved in the RLR signaling pathway. Indeed, Irf $5^{-/-}$mice show a reduction in the serum levels of type I IFNs when challenged with vesicular stomatitis virus (VSV) or Newcastle disease virus (NDV) (Yanai et al. 2007; Paun et al. 2008). More recent study also showed the involvement of IRF5 in West Nile virus or murine norovirus infection- mediated Ifnb gene induction (Lazear et al. 2013). However, the function of IRF5 may be cell type-specific since, unlike macrophages, type I IFN response evoked by VSV infection is normal in Irf5 $5^{-/-}$MEFs (Yanai et al. 2007). Although IRF5 can also be phosphorylated by TBK1, the detailed activation mechanism of IRF5 in the RIG-I signaling pathway is still poorly understood (Lin et al. 2005).

There is report showing that IRF8 is also required for type I IFN induction in virus-stimulated dendritic cells, wherein it binds to the promoters of type I IFN genes and magnifies the late phase of transcription in dendritic cells (Tailor et al. 2007).

\section{IRFs in Cytosolic DNA Sensor Signaling}

In response to cytosolic DNA, STING forms a complex with TBK1 and IRF3 and serves as an adaptor protein that 
links TBK1 to the activation of IRF3 (Ishikawa and Barber 2008; Zhong et al. 2008; Tanaka and Chen 2012; Paludan and Bowie 2013). Recent data indicate that DDX41 and IFI16 are required for the recruitment of STING to activate the TBK1-IRF3-dependent pathway (Unterholzner et al. 2010; Parker et al. 2011; Parvatiyar et al. 2012). LRRFIP1 was also reported to recognize cytosolic dsDNA (Yang et al. 2010), and it interacts with and activates $\beta$-catenin, which induces IFN- $\beta$ expression through binding to IRF3 and recruiting the acetyltransferase p300 to the IFN- $\beta$ promoter (Yang et al. 2010).

\section{IRFS AND TLR SIGNALING}

To date, 13 different TLRs (10 in human and 12 in mice) have been identified and found to recognize a variety of PAMPs derived from bacteria, viruses, fungi, and/or protozoa to trigger immune responses including the induction of type I IFNs and proinflammatory cytokines (Medzhitov 2001; Kawai and Akira 2006b). All TLRs are membrane-bound type receptors which use adaptor proteins MyD88 (myeloid differentiation primary-response protein 88 ) and/or TRIF (TIR domain-containing adaptor including IFN- $\beta$ ) to activate IRFs and other transcription factors.

\section{IRF3 and IRF7 in the TRIF-Dependent Pathway}

TLR4 and TLR3 both use the TRIF adaptor protein to activate IRF3 and induce type I IFNs, albeit weakly as compared to RLR-mediated induction (Fig. 2A) (Negishi et al. 2012). TLR4 is a cell surface receptor that recognizes LPS from gram-negative bacteria and a variety of other PAMPs or DAMPs (damage-associated molecular patterns). TLR4 signaling results in the induction of the genes encoding IFN- $\beta$, but not the genes encoding IFN- $\alpha$ except IFN- $\alpha 4$ (Kawai et al. 2001; Sakaguchi et al. 2003). After activation of TLR4, TRIF recruits TRAF3, NAP1, and TBK1 (Hemmi et al. 2004; Perry et al. 2004; Oganesyan et al. 2006). The induction of IFN- $\beta$ in response to LPS is abolished in $\operatorname{Irf3} 3^{-/-}$dendritic cells, whereas this induction is almost unaffected in $\operatorname{Irf} 7^{-1-}$ cells (Sakaguchi et al. 2003; Honda et al. 2005). Consistent with these results, $\operatorname{Irf} 3^{-1-}$ mice show resistance to LPS-induced endotoxin shock, for which IFN- $\beta$ is critical (Sakaguchi et al. 2003). Thus, IFN- $\beta$ induction by TLR4 is mainly mediated by IRF3, rather than IRF7, via its phosphorylation by TBK 1 .

TLR3 is located within the membrane of endosomes and phagosomes or at the cell surface, in the case of endothelial and natural killer cells (Tamura et al. 2008). TLR3 recognizes the synthetic dsRNA analog poly(rI:rC) and viral dsRNA derived from either dsRNA or short strand RNA (ssRNA) viruses (Alexopoulou et al. 2001; Wang et al. 2004; Rudd et al. 2006). TLR3 is also involved in the defense against infection by some DNA viruses or parasites (Tabeta et al. 2004; Aksoy et al. 2005; Flandin et al. 2006; Zhang et al. 2007). The activation of TLR3, like TLR4, can induce type I IFN expres- sion via a TRIF-dependent pathway. Although IRF3 plays an essential role in this induction, a weak induction of type I IFN mRNAs by poly(rI:rC) is still observed in $\operatorname{Irf} 3^{-}$- dendritic cells. This residual induction was completely abolished in IRF3 and IRF7 doubly deficient dendritic cells (H Negishi and T Taniguchi, unpubl.). Therefore, in contrast to TLR4, IRF3, and IRF7 are both required for TLR3-TRIF-mediated induction of type I IFN genes.

\section{IRF3 and IRF7 in the MyD88-Dependent Pathway}

Plasmacytoid dendritic cells are defined by their massive expression of type I IFNs in response to ligands for TLR7 and TLR9, and unlike conventional dendritic cells, express high amounts of TLR7 and TLR9 in endosomes (Kawai and Akira 2006b). TLR7 recognizes genomic ssRNA of ssRNA viruses, whereas TLR9 recognizes hypomethylated $\mathrm{CpG}$ DNA motifs present in bacteria and DNA viruses. In contrast to TLR3- or TLR4-mediated, TRIF-dependent IFN gene induction, TLR7 and TLR9 exclusively use MyD88 as its signaling adaptor (Fig. 2B).

IRF7, but not IRF3, directly interacts with the death domain of MyD88 (Honda et al. 2004; Kawai et al. 2004) and is essential for the robust MyD88-dependent induction of IFN gene in plasmacytoid dendritic cells. Splenic plasmacytoid dendritic cells derived from $\operatorname{Irf} 7^{-/-}$mice show a profound defect in type I IFN gene induction upon infection by DNA and RNA viruses or treatment with synthetic TLR7 or TLR9 ligands (ssRNA or CpG-A, respectively), while the induction is normal in $\operatorname{Irf} 3^{-/-}$ plasmacytoid dendritic cells (Honda et al. 2005). However, a recent study suggests that IRF3 also participates in the TLR9-MyD88-mediated induction of type I IFN gene in plasmacytoid dendritic cells after Listeria monocytogenes infection by a still unknown mechanism (Stockinger et al. 2009).

IRF7 also interacts with TRAF6 whose overexpression induces type I IFN genes through the activation of IRF7 (Honda et al. 2004). IRAK1 and IRAK4 are signal transducers between MyD88 and TRAF6 and are required for TLR9-mediated IFN- $\alpha$ induction in plasmacytoid dendritic cells. In addition, IKK $\alpha$ is essential for the phosphorylation of IRF7 (Hoshino et al. 2006). Therefore, the IRAK4-IRAK1-IKK $\alpha$ kinase cascade, which is known to operate within the NF- $\mathrm{B}$ activation pathway, also leads to IRF7 activation.

Recently, two DExD/H-box helicases, DHX9 and DHX36, were identified as MyD88-dependent sensors of CpG-containing DNA in plasmacytoid dendritic cells (Kim et al. 2010). DHX36 triggers a pathway specific for IRF7 activation to induce IFN- $\alpha$ expression, whereas DHX9 promotes nuclear translocation of the p50 NF$\kappa \mathrm{B}$ subunit and subsequent induction of NF- $\mathrm{B}$-dependent genes such as TNF- $\alpha$ and IL-6 (Kim et al. 2010; Keating et al. 2011).

\section{Other IRFs in TLR Signaling}

IRF5 is a critical transcription factor for proinflammatory gene induction downstream from the MyD88-depen- 

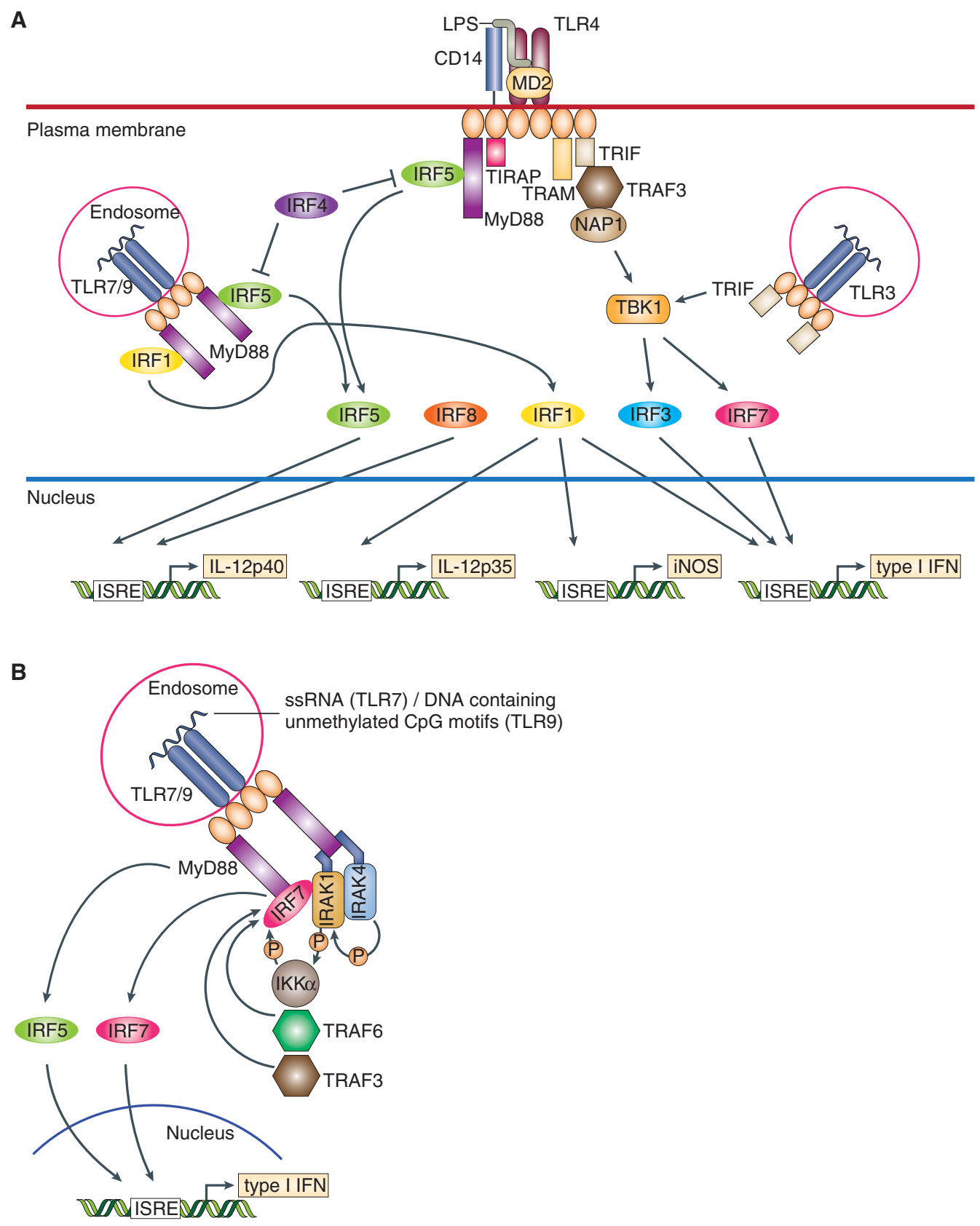

Figure 2. IRFs in TLR-mediated gene induction. (A) TLR4 signals through at least four adaptors: MyD88, TRIF, TIRAP (Toll/ interleukin-1 receptor (TIR)-domain-containing adaptor protein), and TRAM (TRIF-related adaptor molecule). TRAM and TRIF mediate the activation of IRF3. TRIF associates with TBK1 through NAP1 (NAK-associated protein 1) and TRAF3, and then TBK1 phosphorylates IRF3. IRF1 and IRF5 interact with and are activated by MyD88-dependent signaling. IRF4 binds to MyD88 in a region that overlaps the IRF5-binding region, thus inhibiting the binding of IRF5 to MyD88 and attenuating the MyD88-mediated activation of IRF5. Activated IRFs translocate to the nucleus, where they induce transcription of their specific target genes. $(B)$ In plasmacytoid dendritic cells, after activation of TLR7 or TLR9, IRF7 binds to MyD88 and is activated by a protein-kinase cascade that involves IRAK4, IRAK1, and IKKa. TRAF6 and TRAF3 also interact with and activate IRF7.

dent signaling pathway (Takaoka et al. 2005). Similar to IRF7, IRF5 also interacts with MyD88 and TRAF6 (Takaoka et al. 2005). However, unlike IRF7, IRF5 interacts with the central region (the intermediary domain and part of the TIR domain) of MyD88, causing the competition with IRF4 described in more detail below (Negishi et al. 2005). Following TLR activation, IRF5 translocates from the cytoplasm to the nucleus, where it binds to ISREs within promoters of target genes such as $1112 b$. Interestingly, IRF5 also contributes to MyD88-dependent type I IFN gene induction in plasmacytoid dendritic cells stimulated with CpG-B oligonucleotides (Yasuda et al. 2013). Consistent with this report, polymorphisms of the human $\operatorname{Irf} 5$ gene are suggested to be associated with type 
I IFN-related autoimmune diseases, especially systemic lupus erythematosus (SLE) (Graham et al. 2006, 2007).

Although the detailed mechanism for the activation of IRF5 is still not fully elucidated, it is suggested that TRAF6-mediated K63-linked ubiquitination is important for IRF5 nuclear translocation in TLR7/9-MyD88-dependent signaling (Balkhi et al. 2008). In addition, phosphorylation of serine/threonine residues in a carboxyterminal auto-inhibitory region was shown to be a crucial step for dimer formation of IRF5 and interaction with $\mathrm{CBP} / \mathrm{p} 300$ in the nucleus (Chen et al. 2008).

Like IRF5, IRF1 also interacts with the central region of MyD88 (Negishi et al. 2006). Although IRF1 is strongly induced by type II IFN (IFN- $\gamma$ ), IFN- $\gamma$ signaling itself is insufficient to fully activate IRF1. Rather, TLR9 engagement causes MyD88-associated IRF1 to undergo posttranslational modifications and migrate into the nucleus. Thus, IRF1 is critical for the IFN- $\gamma$ enhancement of the TLR-dependent gene induction program.

IRF4 functions in the negative feedback regulation of TLR signaling. Upon TLR activation, Irf4 mRNA is induced and IRF4 protein principally localizes in the nucleus. However, a significant fraction also exists in the cytoplasm where it colocalizes with MyD88. Because IRF4 binds to the same region of MyD88 that IRF5 binds, TLR-induced IRF4 competes with and inhibits the sustained activity of IRF5. Consistent with its role as a negative regulator of TLR signaling, induction of proinflammatory cytokines by TLR stimulation is enhanced in Irf $4^{-1-}$ cells, and Irf4 ${ }^{-1-}$ mice are highly sensitive to endotoxic shock induced by CpG-B (Negishi et al. 2005). IRF4 is also suggested as a negative regulator of TLRmediated NF- $\kappa$ B activation (Honma et al. 2005).

Although IRF8 binds to TRAF6 (Zhao et al. 2006), it has not been shown to bind to MyD88 (Negishi et al. 2005). Its interaction with TRAF6 suggests that IRF8 functions in the cytosol. Indeed, IRF8 participates in the TLR9-MyD88-dependent activation of NF- $\mathrm{KB}$ to induce proinflammatory cytokines such as TNF- $\alpha$ and IL-6 (Tsujimura et al. 2004). On the other hand, IRF8 also acts as a transcription factor which is required for the induction of $I l 12 b$ gene upon various PAMP stimuli in macrophages and dendritic cells, and for the induction of type I IFN genes by viruses and TLR ligands in dendritic cells (Savitsky et al. 2010).

\section{IRFS AND NLR SIGNALING}

The NLR family is comprised of three distinct subfamilies: the NODs (NOD1-2, NOD3/NLRC3, NOD4/ NLRC5, NOD5/NLRX1, and CIITA), the NLRPs (NLRP1-14, also called NALPs), and the IPAF subfamily (Schroder and Tschopp 2010). They perform cytoplasmic surveillance for PAMPs. Among NLR family proteins, NOD2 is reported to mediate ssRNA-induced type I IFN production (Sabbah et al. 2009). Although IRF3 and IRF5 were suggested to be involved in the NOD2-mediated IFN induction (Sabbah et al. 2009; Chang Foreman et al. 2012), it has not yet been fully determined whether other IRFs are involved in the gene regulation by NLRs. The inflamma- some is a protein complex that activates caspase- 1 composed of NLRs, ASC (apoptosis-associated speck-like protein containing a CARD), and caspase-1. Inflammasomes are molecular platforms activated upon cellular infection or stress which trigger the maturation of IL-1 $\beta$ to activate components of innate immune system (Schroder and Tschopp 2010). The role of IRFs in the regulation of inflammasomes has not yet been clarified and further investigation is needed to uncover if and what roles IRFs play in NLR signaling and inflammasome systems.

\section{IRFS AND CLR SIGNALING}

CLRs comprise a large family of receptors that bind to carbohydrates in a calcium-dependent manner (Sancho and Reis e Sousa 2012). CLRs are expressed by most cell types including macrophages and dendritic cells. Dectin-1, a CLR specific for $\beta$-glucans, plays an important role in antifungal innate immunity. Upon binding to its ligand, Dectin-1 triggers phagocytosis and activation of Src and Syk kinases through its ITAM-like motif (Sancho and Reis e Sousa 2012). A recent study showed that IRF5, but not IRF3 or IRF7, acts as a signal mediator under Dectin-1 - Syk pathway and is required for Dectin1 -induced IFN- $\beta$ production (Del Fresno et al. 2013). Indeed, the production of type I IFNs in renal infiltrating dendritic cells, mediated by Dectin-1 - Syk-IRF5 signaling, plays a crucial role in defense against Candida albicans infection (Del Fresno et al. 2013). Further studies are required to elucidate relationships between CLRs and other IRFs.

\section{INTERACTION OF IRFS WITH OTHER TRANSCRIPTION FACTORS}

The cooperation of IRFs with other IRFs and other transcription factors is thought to be an important mechanism by which they control the specificity and magnitude of a transcriptional event. The classic example is IRF9, which forms a heterotrimeric complex with Stat1 and Stat2. This complex, termed ISGF3, is essential for evoking antiviral innate responses by type I and type III IFNs (Levy et al. 2011).

IRFs can also associate with NF- $\mathrm{BB}$ family members to cooperatively regulate the transcription of several cytokine genes. The best known of these is the IFN- $\beta$ gene that requires the coordinated binding of NF- $\mathrm{B}, \mathrm{AP} 1$ (a complex of ATF2 and JUN), and homodimers or heterodimers of IRF3 and IRF7, followed by binding of coactivators CBP or p300 forming a complex termed "the enhanceosome." The interaction between IRFs and NF$\kappa \mathrm{B}$ in this instance occurs through their mutually independent binding to the promoter (Honda and Taniguchi 2006; Panne et al. 2007). IRF3 can also form a complex directly with the NF-кB subunit p65 (or Rel-A) by binding to the Rel-homology domain (RHD) of p65. In this case, IRF3 does not bind to an ISRE, but functions as a promoter-specific and signal-specific cofactor to activate transcription of some NF- $\mathrm{BB}$-dependent genes. It has also 
been shown that IRF3-p65 complexes can support the full induction of ISRE-driven genes in response to TLR4 signaling. Thus, depending on the nature of signaling, IRF3 can either function as a coactivator of p65 for the transcription of NF- $\mathrm{kB}$-dependent genes, or p 65 serves as a cofactor of IRF3 for the transcription of IRF-dependent genes (Wietek et al. 2003; Ogawa et al. 2005). Interestingly, another facet of the cooperation between NF-кB and IRF3 was reported, in which glucocorticoid receptor complex represses TLR-dependent gene expression through IRF3 or NF-кB. Ligand-bound glucocorticoid receptor prevents interactions between $\mathrm{p} 65$ and IRF3 by binding to and competing with IRF3 for the RHD of $\mathrm{p} 65$. As a result, the glucocorticoid receptor represses a large set of inflammatory-response genes (Ogawa et al. 2005).

Recent studies have revealed a mechanism of cell specificity for IRF4 (Glasmacher et al. 2012; Li et al. 2012; Tussiwand et al. 2012). IRF4 is a key regulator of the differentiation of mature B cells into antibody-secreting plasma cells (Shaffer et al. 2009) and contributes to the development of multiple $\mathrm{T}_{\mathrm{H}}$ cell subsets (Pernis 2002; Lohoff and Mak 2005). The mechanism of these cell type-specific functions is partially explained by interaction of IRF4 with other transcription factors ( $\mathrm{Li}$ et al. 2012; Tussiwand et al. 2012). In B cells, the largely Bcell-restricted Ets family transcription factor PU.1 interacts with IRF4 and allows IRF4 to regulate genes whose promoter or enhancer regions contain composite Ets-IRF consensus motif elements (EICEs, GGAAnnGAAA), including immunoglobulin $\kappa$ and $\lambda$ light chain genes (Brass et al. 1996; Escalante et al. 2002). In $\mathrm{T}_{\mathrm{H}} 17$ cells, where PU.1 expression is low, IRF4 instead functionally cooperates with an AP1 family protein BATF to act on AP1IRF consensus motif elements (AICEs, TGAnTCA/ GAAA), resulting in the activation of genes such as Il17a (Glasmacher et al. 2012; Li et al. 2012; Tussiwand et al. 2012). Each IRF-cofactor combination targets a particular set of genes, determined by the cognate binding sequence elements in the regulatory regions of target genes. Through this combinatorial interaction with different transcription factors, IRFs can activate or repress several target genes in a cell type-dependent manner.

\section{IRFS IN CROSS-INTERACTION BETWEEN PRR SIGNALING}

\section{Suppression of TLR-Activated IRF5 by RLR-Activated IRF3}

The innate PRR signaling pathways are known to interact with each other in a variety of ways, including cooperation, complementation, and compensation (Nish and Medzhitov 2011). Recent studies have revealed the involvement of IRFs in the signal cross talk that regulates PRR-mediated gene induction. Cooperation of TLR-induced signaling pathways in response to pathogen is the most well documented type of interaction in situations where more than one TLR ligand is present (Nish and Medzhitov 2011). In particular, MyD88-and TRIF-dependent pathways synergistically activate proinflammatory gene induction. This synergistic gene induction is dependent on IRF5, indicating that both pathways cooperate to activate this transcription factor (Ouyang et al. 2007).

Recently, IRF3 was shown to uniquely participate in a process termed "signaling interference," which defines a new facet of signal cross talk. This occurs between TLRs and cytosolic nucleic acid-sensing receptor pathways, wherein virus-induced activation of the latter pathway results in the selective suppression of bacteria- or TLR-induced $I l 12 b$ gene that encodes the common subunit of IL12 and IL-23, which are critical for driving $\mathrm{T}_{\mathrm{H}} 1$ - and $\mathrm{T}_{\mathrm{H}}$ 17-type $\mathrm{T}$-cell responses, respectively (Negishi et al. 2012; Koshiba et al. 2013). This suppression is mediated by IRF3, which is strongly activated by cytosolically derived nucleic acids. IRF3 binds dominantly to ISREs within both promoter and enhancer, and interferes with the TLR-induced assembly of a productive transcription factor complex by IRF5 (Fig. 3A,B). Consequently, RLR activation by viruses in mice attenuates TLR-induced $\mathrm{T}_{\mathrm{H}} 1$ - and $\mathrm{T}_{\mathrm{H}} 17$-type $\mathrm{T}$-cell responses and viral infection causes lethality at sublethal doses of bacterial infection.

Although the carboxy-terminal region of IRF3 determines its cooperation with other transcription factors, its amino-terminal DNA-binding region was shown to be critical for IRF3-mediated $I l 12 b$ gene suppression (Koshiba et al. 2013). Interestingly, in the $I l 12 b$ promoter/ enhancer, the $5^{\prime} \mathrm{AA}$ dinucleotide sequence of ISRE, which interacts with the His40 residue within loop 1 (L1 loop) of IRF3, deviates from consensus ISRE in all enhancer and promoter ISREs known to be activated by IRF3. Of note, these deviated ISRE sequences are found among other mammalian species, which may indicate an evolutional significance of this deviation (Koshiba et al. 2013). The alteration of this binding sequence to a genuine ISRE sequence allows the $I l 12 b$ promoter/enhancer to be transcriptionally activated by IRF3, which further supports the importance of this binding sequence. Thus, the interaction of IRF3 with the "deviated" ISREs sequence may cause IRF3 to undergo a conformational change distinctly different from IRF3 bound to the "consensus" AA sequence and render IRF3 to induce a transcriptionally inactive state (Fig. 3C) (Koshiba et al. 2013). Under the same conditions, TLR-activated IRF3 mediates the cooperative induction of other genes such as $I l 33$ and $T s l p$, both of which contain "genuine" ISREs within their promoters. Since these cytokines are known to promote $\mathrm{T}_{\mathrm{H}}$ 2-type $\mathrm{T}$ cell responses, the dual function of virus-activated IRF3, namely, suppression of $I l 12 b$ gene and activation of $I l 33$ and Tslp genes may account for the enhanced $\mathrm{T}_{\mathrm{H}} 2$ response in virally infected mice (Negishi et al. 2012).

\section{Immunological Consequences of IRF3-Mediated Signaling Cross-Interference}

The above observations may have implications for several immunopathological conditions. For instance, viral infections that activate RIG-I are implicated in triggering asthma with manifestations of a $\mathrm{T}_{\mathrm{H}} 2$ signature, and patients infected by human immunodeficiency virus (HIV), known to activate IRF3, are more susceptible to infec- 
A
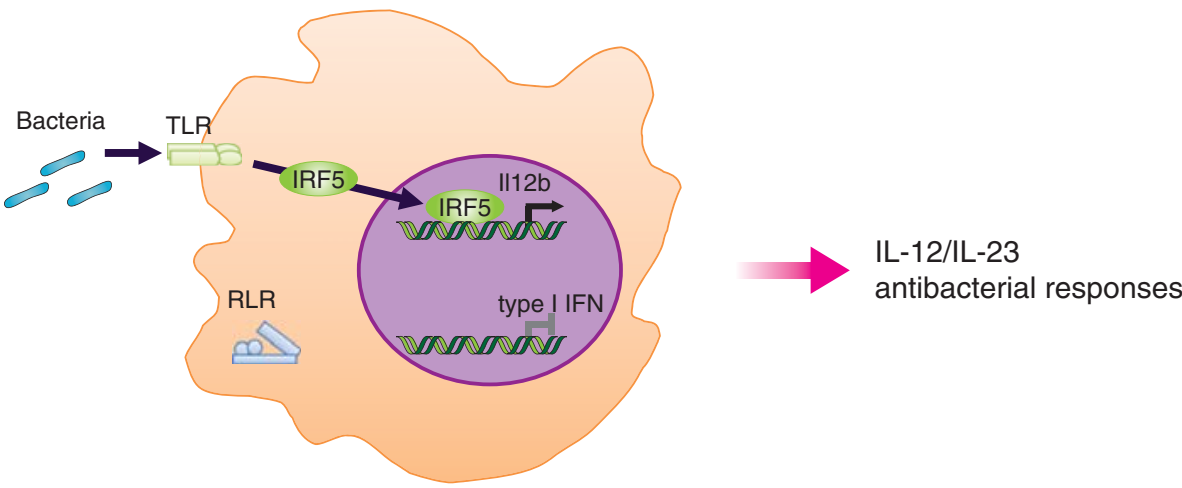

B

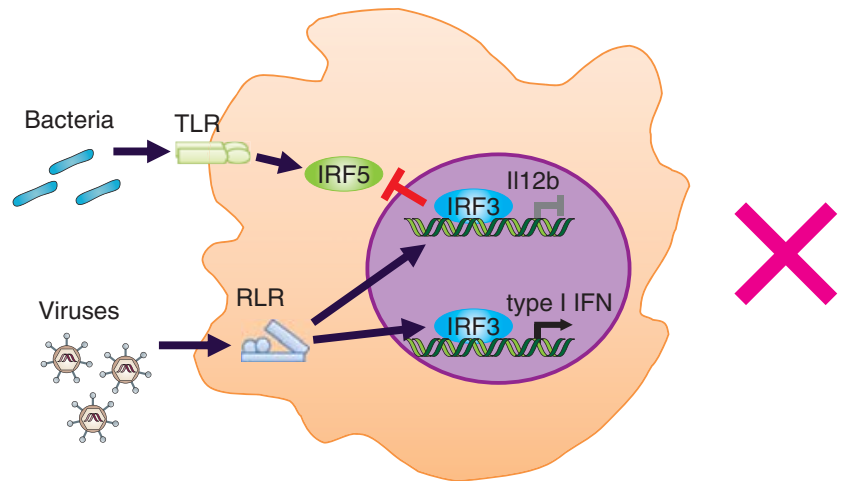

C

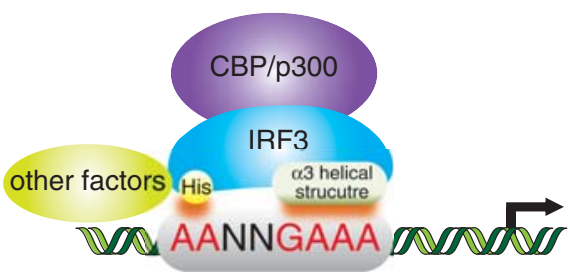

"genuine" ISRE

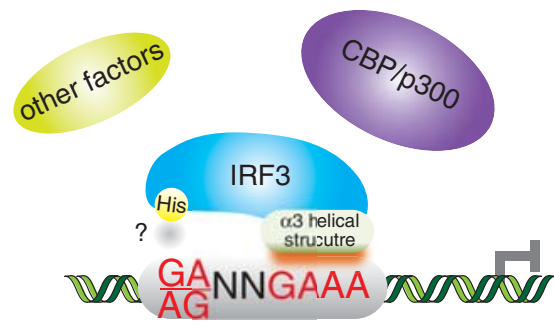

"deviated" ISRE

Figure 3. Schematic illustrations of IRF3-mediated cross-interference between TLR and RLR. $(A)$ The Ill2b gene is induced through a TLR-IRF5-mediated pathway upon bacterial infection, causing promotion of $\mathrm{T}_{\mathrm{H}} 1$ - and $\mathrm{T}_{\mathrm{H}} 17$-type antibacterial $\mathrm{T}$-cell responses. (B) In the case of simultaneous infection with viruses and bacteria, RLR stimulation by viruses results in the dominant binding of IRF3 over bacteria- and TLR-activated IRF5 to the promoter/enhancer of the $I l 12 b$ gene; this is accompanied by a loss of C/EBP $\beta$ and Oct-2 recruitment, thereby inhibiting TLR-induced gene expression (Negishi et al. 2012; Koshiba et al. 2013). (C) The IRF3-mediated suppression of $I l 12 \mathrm{~b}$ promoter/enhancer; a speculative view. Activated IRF3 binds to its target genes, such as Ifnb, Il 33 and Tslp, and recruits other factors/coactivators to activate gene transcription (left panel). On the other hand, IRF3 interacts with ISREs containing the "deviated" $5^{\prime}$ AA sequence of the $I l 12 b$ gene and undergoes a conformational change that is different from IRF3 bound to the "consensus" AA sequence (right panel). This conformational change may render IRF3 to induce a transcriptionally inactive state, whereas IRF5 interactions to these deviated ISREs can mediate "productive" complex formation. Supporting this notion are data showing that the enhancer and promoter could be converted from "IRF3-repressible" to "IRF3-activatable" when these deviated sequences were converted to the "consensus" AA sequence. However, this view needs further elaboration.

tious agents that typically generate $\mathrm{T}_{\mathrm{H}} 1$-type responses (Holt and Sly 2002; Manel et al. 2010). Thus, enhanced $\mathrm{T}_{\mathrm{H}} 2$-type and attenuated $\mathrm{T}_{\mathrm{H}} 1 / \mathrm{T}_{\mathrm{H}} 17$ responses, which result from viral infections and for which the RLR-IRF3 axis is critical, may account, at least in part, for the development of these pathogenic events.

What is the evolutional significances of the intricate regulatory mechanism that switches IRF3 to become a transcriptional suppressor? It might have arisen and been selected to hedge the risk(s) of immune pathogenesis by which the system balances intrinsic "pros and cons" to maintain the host's delicate homeostasis. Thus, upon viral infection, a robust activation of the innate immune system, a hallmark of which is the induction of type I IFN genes by IRF3, is of immediate necessity as the first line of defense of the host. On the other hand, the antiviral 
responses, if left uncontrolled, may increase the risk of excessive and sometimes life-threatening inflammation, or perhaps, under chronic conditions, to predispose the host toward autoimmunity, characterized by excessive $\mathrm{T}_{\mathrm{H}} 1$ and $\mathrm{T}_{\mathrm{H}} 17$-type responses. Indeed, there is ample evidence for the involvement of type I IFN signaling per se to the development or progression of autoimmunity (Banchereau and Pascual 2006; Trinchieri 2010). Therefore, antiviral responses may be viewed as a "doubleedged sword" in immunity. In this context, the induction of type I IFNs for antiviral responses fulfills the "pros," whereas the suppression of inflammatory immune responses, by suppressing $I l 12 b$ expression, is a means to minimize the "cons" of the responses. In short, IRF3 may serve as a guardian of homeostatic immune responses. It will be interesting to examine whether other types of signaling cross-interference also operate for the fine-tuning of the innate receptor-mediated immune responses.

\section{CONCLUDING REMARKS}

The IRF family of transcription factors was first identified as regulators of type I IFN gene induction. However, the detailed mechanisms of how IRFs exert their functions in response to viruses or their mimetics remained elusive until the discovery of signal-transducing PRRs. Indeed, the discovery of the various classes of PRRs brought about a breakthrough in the understanding of how viruses and other pathogens trigger signaling events that lead to the activation of IRFs and other transcription factors. As described in this and other articles, much is now known about how each of these IRFs participates in the gene regulation programs downstream from PRRs. However, the history of this family is relatively new as compared to other well-studied transcription factors, such as NF-кB. Therefore, one may anticipate there are much more broadly-acting functions of IRFs in the regulation of immune responses. It is also clear that the functional diversity of IRFs is driven by their interactions with IRF and other binding partners.

In addition to inducing type I IFN gene expressions, IRFs also serve to sustain or enhance type I IFN gene induction upon viral infections. IRF3 and IRF7 are structurally related and likely evolved from a common ancestor. The IRF7 gene is under the control of IFN signaling for further amplification of the IFN response against viral infections. In fact, multiple IFN- $\alpha$ genes themselves may also have evolved to enhance the IFN-mediated antiviral immune response, and IFN- $\alpha$ and $-\beta$ genes have diverged from a common ancestor (Taniguchi et al. 1980; Honda and Taniguchi 2006; Tamura et al. 2008). Of note, the induction of most IFN- $\alpha$ genes is dependent on IFN- $\beta$, the signaling of which induces IRF7 gene expression. The evolution of these positive-feedback mechanisms must have been beneficial or even essential for the antiviral immunity of the host (Honda and Taniguchi 2006).

Although the beneficial aspects of the type I IFN system on the host defense against viral infection are evident, data also suggest the aberrant activation of type I IFNs contributes to the development of autoimmune diseases, such as SLE (Banchereau and Pascual 2006). SLE patients are characterized by the production of autoantibodies to cellular macromolecules, typically self-nucleic acids, and these autoantibodies to nucleic acids form immune complexes that can be taken up into endosomes of pDCs or other cells to stimulate TLR7 or TLR9 to produce type I IFNs. Thus, self-RNA and -DNA are potentially immunogenic, and the aberrant activation of these TLRs for type I IFN induction might be responsible for the pathogenesis of autoimmune diseases. IRF5 is another member whose contribution to SLE has gained much attention (Deng and Tsao 2010). Thus, better understanding of how these signaling pathways are turned on and off by the IRF system will be important for the development of new therapeutic interventions for infectious, inflammatory, and autoimmune diseases.

\section{ACKNOWLEDGMENTS}

We apologize to all of the authors whose invaluable work we could not discuss or cite in this review due to space constraints. This work was supported in part by the Core Research for Evolutional Science and Technology (CREST) of JST, a Grant-in-Aid for Exploratory Research of MEXT, and a Grant-In-Aid for Scientific Research on Innovative Areas of MEXT.

\section{REFERENCES}

Ablasser A, Bauernfeind F, Hartmann G, Latz E, Fitzgerald KA, Hornung V. 2009. RIG-I-dependent sensing of poly(dA:dT) through the induction of an RNA polymerase III-transcribed RNA intermediate. Nat Immunol 10: 1065-1072.

Aksoy E, Zouain CS, Vanhoutte F, Fontaine J, Pavelka N, Thieblemont N, Willems F, Ricciardi-Castagnoli P, Goldman M, Capron M, et al. 2005. Double-stranded RNAs from the helminth parasite Schistosoma activate TLR3 in dendritic cells. $J$ Biol Chem 280: 277-283.

Alexopoulou L, Holt AC, Medzhitov R, Flavell RA. 2001. Recognition of double-stranded RNA and activation of NF- $\mathrm{KB}$ by Toll-like receptor 3. Nature 413: 732-738

Andrejeva J, Childs KS, Young DF, Carlos TS, Stock N, Goodbourn S, Randall RE. 2004. The V proteins of paramyxoviruses bind the IFN-inducible RNA helicase, mda-5, and inhibit its activation of the IFN- $\beta$ promoter. Proc Natl Acad Sci 101: 17264-17269.

Balkhi MY, Fitzgerald KA, Pitha PM. 2008. Functional regulation of MyD88-activated interferon regulatory factor 5 by K63-linked polyubiquitination. Mol Cell Biol 28: 72967308.

Banchereau J, Pascual V. 2006. Type I interferon in systemic lupus erythematosus and other autoimmune diseases. Iтmиnity 25: 383-392.

Blasius AL, Beutler B. 2010. Intracellular Toll-like receptors. Immunity 32: 305-315.

Brass AL, Kehrli E, Eisenbeis CF, Storb U, Singh H. 1996. Pip, a lymphoid-restricted IRF, contains a regulatory domain that is important for autoinhibition and ternary complex formation with the Ets factor PU.1. Genes Dev 10: 2335-2347.

Burdette DL, Monroe KM, Sotelo-Troha K, Iwig JS, Eckert B, Hyodo M, Hayakawa Y, Vance RE. 2011. STING is a direct innate immune sensor of cyclic di-GMP. Nature 478: 515518 
Chang Foreman HC, Van Scoy S, Cheng TF, Reich NC. 2012. Activation of interferon regulatory factor 5 by site specific phosphorylation. PloS One 7: e33098.

Chen W, Royer WE Jr. 2010. Structural insights into interferon regulatory factor activation. Cell Signal 22: 883-887.

Chen W, Lam SS, Srinath H, Jiang Z, Correia JJ, Schiffer CA, Fitzgerald KA, Lin K, Royer WE Jr. 2008. Insights into interferon regulatory factor activation from the crystal structure of dimeric IRF5. Nat Struct Mol Biol 15: 1213-1220.

Childs KS, Randall RE, Goodbourn S. 2013. LGP2 plays a critical role in sensitizing mda-5 to activation by doublestranded RNA. PloS One 8: e64202.

Chiu YH, Macmillan JB, Chen ZJ. 2009. RNA polymerase III detects cytosolic DNA and induces type I interferons through the RIG-I pathway. Cell 138: 576-591.

Choi MK, Wang Z, Ban T, Yanai H, Lu Y, Koshiba R, Nakaima Y, Hangai S, Savitsky D, Nakasato M, et al. 2009. A selective contribution of the RIG-I-like receptor pathway to type I interferon responses activated by cytosolic DNA. Proc Natl Acad Sci 106: 17870-17875.

Darnell JE Jr, Kerr IM, Stark GR. 1994. Jak-STAT pathways and transcriptional activation in response to IFNs and other extracellular signaling proteins. Science 264: 1415-1421.

DeFilippis VR, Alvarado D, Sali T, Rothenburg S, Fruh K. 2010. Human cytomegalovirus induces the interferon response via the DNA sensor ZBP1. J Virol 84: 585-598.

Del Fresno C, Soulat D, Roth S, Blazek K, Udalova I, Sancho D, Ruland J, Ardavin C. 2013. Interferon- $\beta$ production via Dectin-1-Syk-IRF5 signaling in dendritic cells is crucial for immunity to C. albicans. Immunity 38: 1176-1186.

Deng Y, Tsao BP. 2010. Genetic susceptibility to systemic lupus erythematosus in the genomic era. Nat Rev Rheumatol 6: 683-692.

Escalante CR, Yie J, Thanos D, Aggarwal AK. 1998. Structure of IRF-1 with bound DNA reveals determinants of interferon regulation. Nature 391: 103-106.

Escalante CR, Brass AL, Pongubala JM, Shatova E, Shen L, Singh H, Aggarwal AK. 2002. Crystal structure of PU.1/ IRF-4/DNA ternary complex. Mol Cell 10: 1097-1105.

Fitzgerald KA, McWhirter SM, Faia KL, Rowe DC, Latz E, Golenbock DT, Coyle AJ, Liao SM, Maniatis T. 2003. IKK $\epsilon$ and TBK1 are essential components of the IRF3 signaling pathway. Nat Immunol 4: 491-496.

Flandin JF, Chano F, Descoteaux A. 2006. RNA interference reveals a role for TLR2 and TLR3 in the recognition of Leishmania donovani promastigotes by interferon- $\gamma$-primed macrophages. Eur J Immunol 36: 411-420.

Fritz JH, Ferrero RL, Philpott DJ, Girardin SE. 2006. Nod-like proteins in immunity, inflammation and disease. Nat Immunol 7: $1250-1257$.

Fujii Y, Shimizu T, Kusumoto M, Kyogoku Y, Taniguchi T, Hakoshima T. 1999. Crystal structure of an IRF-DNA complex reveals novel DNA recognition and cooperative binding to a tandem repeat of core sequences. EMBO J 18: $5028-$ 5041.

Glasmacher E, Agrawal S, Chang AB, Murphy TL, Zeng W, Vander Lugt B, Khan AA, Ciofani M, Spooner CJ, Rutz S, et al. 2012. A genomic regulatory element that directs assembly and function of immune-specific AP-1-IRF complexes. Science 338: 975-980.

Graham RR, Kozyrev SV, Baechler EC, Reddy MV, Plenge RM, Bauer JW, Ortmann WA, Koeuth T, Gonzalez Escribano MF, Pons-Estel B, et al. 2006. A common haplotype of interferon regulatory factor 5 (IRF5) regulates splicing and expression and is associated with increased risk of systemic lupus erythematosus. Nat Genet 38: 550-555.

Graham RR, Kyogoku C, Sigurdsson S, Vlasova IA, Davies LR, Baechler EC, Plenge RM, Koeuth T, Ortmann WA, Hom G, et al. 2007. Three functional variants of IFN regulatory factor 5 (IRF5) define risk and protective haplotypes for human lupus. Proc Natl Acad Sci 104: 6758-6763.

Grivennikov SI, Greten FR, Karin M. 2010. Immunity, inflammation, and cancer. Cell 140: 883-899.
Hayden MS, Ghosh S. 2008. Shared principles in NF-кB signaling. Cell 132: 344-362.

Hemmi H, Takeuchi O, Sato S, Yamamoto M, Kaisho T, Sanjo H, Kawai T, Hoshino K, Takeda K, Akira S. 2004. The roles of two IкB kinase-related kinases in lipopolysaccharide and double stranded RNA signaling and viral infection. $J$ Exp Med 199: 1641-1650.

Holm CK, Paludan SR, Fitzgerald KA. 2013. DNA recognition in immunity and disease. Curr Opin Immunol 25: 13-18.

Holt PG, Sly PD. 2002. Interactions between RSV infection, asthma, and atopy: Unraveling the complexities. $J$ Exp Med 196: $1271-1275$.

Honda K, Taniguchi T. 2006. IRFs: Master regulators of signalling by Toll-like receptors and cytosolic pattern-recognition receptors. Nat Rev Immunol 6: 644-658.

Honda K, Yanai H, Mizutani T, Negishi H, Shimada N, Suzuki N, Ohba Y, Takaoka A, Yeh WC, Taniguchi T. 2004. Role of a transductional-transcriptional processor complex involving MyD88 and IRF-7 in Toll-like receptor signaling. Proc Natl Acad Sci 101: 15416-15421.

Honda K, Yanai H, Negishi H, Asagiri M, Sato M, Mizutani T, Shimada N, Ohba Y, Takaoka A, Yoshida N, et al. 2005. IRF7 is the master regulator of type-I interferon-dependent immune responses. Nature 434: 772-777.

Honma K, Udono H, Kohno T, Yamamoto K, Ogawa A, Takemori T, Kumatori A, Suzuki S, Matsuyama T, Yui K. 2005. Interferon regulatory factor 4 negatively regulates the production of proinflammatory cytokines by macrophages in response to LPS. Proc Natl Acad Sci 102: 16001-16006.

Hoshino K, Sugiyama T, Matsumoto M, Tanaka T, Saito M, Hemmi H, Ohara O, Akira S, Kaisho T. 2006. IкB kinase- $\alpha$ is critical for interferon- $\alpha$ production induced by Toll-like receptors 7 and 9. Nature 440: 949-953.

Ikushima H, Miyazono K. 2010. TGF $\beta$ signalling: A complex web in cancer progression. Nat Rev Cancer 10: 415-424.

Ishii KJ, Kawagoe T, Koyama S, Matsui K, Kumar H, Kawai T, Uematsu S, Takeuchi O, Takeshita F, Coban C, et al. 2008. TANK-binding kinase-1 delineates innate and adaptive immune responses to DNA vaccines. Nature 451: 725-729.

Ishikawa H, Barber GN. 2008. STING is an endoplasmic reticulum adaptor that facilitates innate immune signalling. Nature 455: 674-678.

Janeway CA Jr, Medzhitov R. 2002. Innate immune recognition. Annu Rev Immunol 20: 197-216.

Kato H, Takeuchi O, Sato S, Yoneyama M, Yamamoto M, Matsui K, Uematsu S, Jung A, Kawai T, Ishii KJ, et al. 2006. Differential roles of MDA5 and RIG-I helicases in the recognition of RNA viruses. Nature 441: 101-105.

Kato H, Takeuchi O, Mikamo-Satoh E, Hirai R, Kawai T, Matsushita K, Hiiragi A, Dermody TS, Fujita T, Akira S. 2008. Length-dependent recognition of double-stranded ribonucleic acids by retinoic acid-inducible gene-I and melanoma differentiation-associated gene 5. J Exp Med 205: 1601-1610.

Kawai T, Akira S. 2006a. Innate immune recognition of viral infection. Nat Immunol 7: 131-137.

Kawai T, Akira S. 2006b. TLR signaling. Cell Death Differ 13: 816-825.

Kawai T, Akira S. 2011. Toll-like receptors and their crosstalk with other innate receptors in infection and immunity. Immunity 34: 637-650.

Kawai T, Takeuchi O, Fujita T, Inoue J, Muhlradt PF, Sato S, Hoshino K, Akira S. 2001. Lipopolysaccharide stimulates the MyD88-independent pathway and results in activation of IFN-regulatory factor 3 and the expression of a subset of lipopolysaccharide-inducible genes. J Immunol 167: 5887-5894.

Kawai T, Sato S, Ishii KJ, Coban C, Hemmi H, Yamamoto M, Terai K, Matsuda M, Inoue J, Uematsu S, et al. 2004. Interferon- $\alpha$ induction through Toll-like receptors involves a direct interaction of IRF7 with MyD88 and TRAF6. Nat Immunol 5: 1061-1068.

Keating SE, Baran M, Bowie AG. 2011. Cytosolic DNA sensors regulating type I interferon induction. Trends Immunol 32: $574-581$. 
Kim T, Pazhoor S, Bao M, Zhang Z, Hanabuchi S, Facchinetti V, Bover L, Plumas J, Chaperot L, Qin J, et al. 2010. Aspartateglutamate-alanine-histidine box motif (DEAH)/RNA helicase A helicases sense microbial DNA in human plasmacytoid dendritic cells. Proc Natl Acad Sci 107: 15181-15186.

Koshiba R, Yanai H, Matsuda A, Goto A, Nakajima A, Negishi H, Nishio J, Smale ST, Taniguchi T. 2013. Regulation of cooperative function of the Il12b enhancer and promoter by the interferon regulatory factors 3 and 5. Biochem Biophys Res Commun 430: 95-100.

Lazear HM, Lancaster A, Wilkins C, Suthar MS, Huang A, Vick SC, Clepper L, Thackray L, Brassil MM, Virgin HW, et al 2013. IRF-3, IRF-5, and IRF-7 coordinately regulate the type I IFN response in myeloid dendritic cells downstream of MAVS signaling. PLoS Pathog 9: e1003118.

Levy DE, Marie IJ, Durbin JE. 2011. Induction and function of type I and III interferon in response to viral infection. Curr Opin Virol 1: 476-486.

Li P, Spolski R, Liao W, Wang L, Murphy TL, Murphy KM, Leonard WJ. 2012. BATF-JUN is critical for IRF4-mediated transcription in T cells. Nature 490: $543-546$

Lin R, Yang L, Arguello M, Penafuerte C, Hiscott J. 2005. A CRM1-dependent nuclear export pathway is involved in the regulation of IRF-5 subcellular localization. J Biol Chem 280: 3088-3095.

Lohoff M, Mak TW. 2005. Roles of interferon-regulatory factors in T-helper-cell differentiation. Nat Rev Immunol 5: 125135.

Loo YM, Gale M Jr. 2011. Immune signaling by RIG-I-like receptors. Immunity 34: 680-692.

Manel N, Hogstad B, Wang Y, Levy DE, Unutmaz D, Littman DR. 2010. A cryptic sensor for HIV-1 activates antiviral innate immunity in dendritic cells. Nature 467: 214-217.

Medzhitov R. 2001. Toll-like receptors and innate immunity. Nat Rev Immunol 1: 135-145.

Negishi H, Ohba Y, Yanai H, Takaoka A, Honma K, Yui K, Matsuyama T, Taniguchi T, Honda K. 2005. Negative regulation of Toll-like-receptor signaling by IRF-4. Proc Natl Acad Sci 102: 15989-15994.

Negishi H, Fujita Y, Yanai H, Sakaguchi S, Ouyang X, Shinohara M, Takayanagi H, Ohba Y, Taniguchi T, Honda K. 2006. Evidence for licensing of IFN- $\gamma$-induced IFN regulatory factor 1 transcription factor by MyD88 in Toll-like receptordependent gene induction program. Proc Natl Acad Sci 103: $15136-15141$

Negishi H, Yanai H, Nakajima A, Koshiba R, Atarashi K, Matsuda A, Matsuki K, Miki S, Doi T, Aderem A, et al. 2012 Cross-interference of RLR and TLR signaling pathways modulates antibacterial T cell responses. Nat Immunol 13: 659666.

Nish S, Medzhitov R. 2011. Host defense pathways: Role of redundancy and compensation in infectious disease phenotypes. Immunity 34: 629-636.

Oganesyan G, Saha SK, Guo B, He JQ, Shahangian A, Zarnegar B, Perry A, Cheng G. 2006. Critical role of TRAF3 in the Toll-like receptor-dependent and -independent antiviral response. Nature 439: 208-211.

Ogawa S, Lozach J, Benner C, Pascual G, Tangirala RK, Westin S, Hoffmann A, Subramaniam S, David M, Rosenfeld MG, et al. 2005. Molecular determinants of crosstalk between nuclear receptors and toll-like receptors. Cell 122: 707-721.

Ouyang X, Negishi H, Takeda R, Fujita Y, Taniguchi T, Honda K. 2007. Cooperation between MyD88 and TRIF pathways in TLR synergy via IRF5 activation. Biochem Biophys Res Commun 354: 1045-1051.

Paludan SR, Bowie AG. 2013. Immune sensing of DNA. Immunity 38: $870-880$.

Panne D, Maniatis T, Harrison SC. 2007. An atomic model of the interferon- $\beta$ enhanceosome. Cell 129: 1111-1123.

Parker D, Martin FJ, Soong G, Harfenist BS, Aguilar JL, Ratner AJ, Fitzgerald KA, Schindler C, Prince A. 2011. Streptococcus pneumoniae DNA initiates type I interferon signaling in the respiratory tract. MBio 2: e00016-00011.
Parvatiyar K, Zhang Z, Teles RM, Ouyang S, Jiang Y, Iyer SS, Zaver SA, Schenk M, Zeng S, Zhong W, et al. 2012. The helicase DDX41 recognizes the bacterial secondary messengers cyclic di-GMP and cyclic di-AMP to activate a type I interferon immune response. Nat Immunol 13: 11551161.

Paun A, Reinert JT, Jiang Z, Medin C, Balkhi MY, Fitzgerald KA, Pitha PM. 2008. Functional characterization of murine interferon regulatory factor 5 (IRF-5) and its role in the innate antiviral response. J Biol Chem 283: $14295-14308$.

Pernis AB. 2002. The role of IRF-4 in B and T cell activation and differentiation. J Interferon Cytokine Res 22: 111-120.

Perry AK, Chow EK, Goodnough JB, Yeh WC, Cheng G. 2004. Differential requirement for TANK-binding kinase-1 in type I interferon responses to toll-like receptor activation and viral infection. J Exp Med 199: 1651-1658.

Rudd BD, Smit JJ, Flavell RA, Alexopoulou L, Schaller MA, Gruber A, Berlin AA, Lukacs NW. 2006. Deletion of TLR3 alters the pulmonary immune environment and mucus production during respiratory syncytial virus infection. J Iтmunol 176: 1937-1942.

Sabbah A, Chang TH, Harnack R, Frohlich V, Tominaga K, Dube PH, Xiang Y, Bose S. 2009. Activation of innate immune antiviral responses by Nod2. Nat Immunol 10: 10731080.

Sakaguchi S, Negishi H, Asagiri M, Nakajima C, Mizutani T, Takaoka A, Honda K, Taniguchi T. 2003. Essential role of IRF-3 in lipopolysaccharide-induced interferon- $\beta$ gene expression and endotoxin shock. Biochem Biophys Res Commun 306: $860-866$.

Sancho D, Reis e Sousa C. 2012. Signaling by myeloid C-type lectin receptors in immunity and homeostasis. Аnnu Rev Immunol 30: 491-529.

Savitsky D, Tamura T, Yanai H, Taniguchi T. 2010. Regulation of immunity and oncogenesis by the IRF transcription factor family. Cancer Immunol Immunother 59: 489-510.

Schroder K, Tschopp J. 2010. The inflammasomes. Cell 140: $821-832$.

Shaffer AL, Emre NC, Romesser PB, Staudt LM. 2009. IRF4: Immunity. Malignancy! Therapy? Clin Cancer Res 15: 2954-2961.

Sharf R, Meraro D, Azriel A, Thornton AM, Ozato K, Petricoin EF, Larner AC, Schaper F, Hauser H, Levi BZ. 1997. Phosphorylation events modulate the ability of interferon consensus sequence binding protein to interact with interferon regulatory factors and to bind DNA. J Biol Chem 272: 9785-9792.

Sharma S, tenOever BR, Grandvaux N, Zhou GP, Lin R, Hiscott J. 2003. Triggering the interferon antiviral response through an IKK-related pathway. Science 300: 1148-1151.

Stockinger S, Kastner R, Kernbauer E, Pilz A, Westermayer S, Reutterer B, Soulat D, Stengl G, Vogl C, Frenz T, et al. 2009. Characterization of the interferon-producing cell in mice infected with Listeria monocytogenes. PLoS Pathog 5: e1000355.

Sun L, Wu J, Du F, Chen X, Chen ZJ. 2013. Cyclic GMP-AMP synthase is a cytosolic DNA sensor that activates the type I interferon pathway. Science 339: 786-791.

Tabeta K, Georgel P, Janssen E, Du X, Hoebe K, Crozat K, Mudd S, Shamel L, Sovath S, Goode J, et al. 2004. Tolllike receptors 9 and 3 as essential components of innate immune defense against mouse cytomegalovirus infection. Proc Natl Acad Sci 101: 3516-3521.

Tailor P, Tamura T, Kong HJ, Kubota T, Kubota M, Borghi P, Gabriele L, Ozato K. 2007. The feedback phase of type I interferon induction in dendritic cells requires interferon regulatory factor 8. Immunity 27: 228-239.

Takaoka A, Yanai H, Kondo S, Duncan G, Negishi H, Mizutani T, Kano S, Honda K, Ohba Y, Mak TW, et al. 2005. Integral role of IRF-5 in the gene induction programme activated by Toll-like receptors. Nature 434: 243-249.

Takaoka A, Wang Z, Choi MK, Yanai H, Negishi H, Ban T, Lu Y, Miyagishi M, Kodama T, Honda K, et al. 2007. DAI 
(DLM-1/ZBP1) is a cytosolic DNA sensor and an activator of innate immune response. Nature 448: 501-505.

Takaoka A, Tamura T, Taniguchi T. 2008. Interferon regulatory factor family of transcription factors and regulation of oncogenesis. Cancer Sci 99: 467-478.

Takeuchi O, Akira S. 2009. Innate immunity to virus infection. Immunol Rev 227: 75-86.

Takeuchi O, Akira S. 2010. Pattern recognition receptors and inflammation. Cell 140: 805-820.

Tamura T, Yanai H, Savitsky D, Taniguchi T. 2008. The IRF family transcription factors in immunity and oncogenesis. Annu Rev Immunol 26: 535-584.

Tanaka Y, Chen ZJ. 2012. STING specifies IRF3 phosphorylation by TBK1 in the cytosolic DNA signaling pathway. Sci Signal 5: ra20.

Taniguchi T, Mantei N, Schwarzstein M, Nagata S, Muramatsu M, Weissmann C. 1980. Human leukocyte and fibroblast interferons are structurally related. Nature 285: 547-549.

Tjian R, Maniatis T. 1994. Transcriptional activation: A complex puzzle with few easy pieces. Cell 77: $5-8$.

Trinchieri G. 2010. Type I interferon: Friend or foe? J Exp Med 207: 2053-2063.

Tsujimura H, Tamura T, Kong HJ, Nishiyama A, Ishii KJ, Klinman DM, Ozato K. 2004. Toll-like receptor 9 signaling activates NF-kappaB through IFN regulatory factor-8/IFN consensus sequence binding protein in dendritic cells. $J$ Immunol 172: 6820-6827.

Tussiwand R, Lee WL, Murphy TL, Mashayekhi M, Wumesh KC, Albring JC, Satpathy AT, Rotondo JA, Edelson BT, Kretzer NM, et al. 2012. Compensatory dendritic cell development mediated by BATF-IRF interactions. Nature 490: 502-507.

Unterholzner L, Keating SE, Baran M, Horan KA, Jensen SB, Sharma S, Sirois CM, Jin T, Latz E, Xiao TS, et al. 2010. IFI16 is an innate immune sensor for intracellular DNA. Nat Immunol 11: 997-1004.

Wang T, Town T, Alexopoulou L, Anderson JF, Fikrig E, Flavell RA. 2004. Toll-like receptor 3 mediates West Nile virus entry into the brain causing lethal encephalitis. Nat Med 10: 13661373.

Wang Z, Choi MK, Ban T, Yanai H, Negishi H, Lu Y, Tamura T, Takaoka A, Nishikura K, Taniguchi T. 2008. Regulation of innate immune responses by DAI (DLM-1/ZBP1) and other DNA-sensing molecules. Proc Natl Acad Sci 105: 54775482.

Wietek C, Miggin SM, Jefferies CA, O’Neill LA. 2003. Interferon regulatory factor-3-mediated activation of the interferon-sensitive response element by Toll-like receptor (TLR) 4 but not TLR3 requires the $\mathrm{p} 65$ subunit of NF-кB. J Biol Chem 278: 50923-50931.

Wu J, Sun L, Chen X, Du F, Shi H, Chen C, Chen ZJ. 2013. Cyclic GMP-AMP is an endogenous second messenger in innate immune signaling by cytosolic DNA. Science 339: $826-830$.
Yanai H, Chen HM, Inuzuka T, Kondo S, Mak TW, Takaoka A, Honda K, Taniguchi T. 2007. Role of IFN regulatory factor 5 transcription factor in antiviral immunity and tumor suppression. Proc Natl Acad Sci 104: 3402-3407.

Yanai H, Ban T, Wang Z, Choi MK, Kawamura T, Negishi H, Nakasato M, Lu Y, Hangai S, Koshiba R, et al. 2009. HMGB proteins function as universal sentinels for nucleicacid-mediated innate immune responses. Nature 462: 99103.

Yanai H, Negishi H, Taniguchi T. 2012. The IRF family of transcription factors: Inception, impact and implications in oncogenesis. Oncoimmunology 1: 1376-1386.

Yang P, An H, Liu X, Wen M, Zheng Y, Rui Y, Cao X. 2010. The cytosolic nucleic acid sensor LRRFIP1 mediates the production of type I interferon via a $\beta$-catenin-dependent pathway. Nat Immunol 11: 487-494.

Yasuda K, Nundel K, Watkins AA, Dhawan T, Bonegio RG, Ubellacker JM, Marshak-Rothstein A, Rifkin IR. 2013. Phenotype and function of B cells and dendritic cells from interferon regulatory factor 5 -deficient mice with and without a mutation in DOCK2. Int Immunol 25: 295-306.

Yin Q, Tian Y, Kabaleeswaran V, Jiang X, Tu D, Eck MJ, Chen ZJ, Wu H. 2012. Cyclic di-GMP sensing via the innate immune signaling protein STING. Mol Cell 46: 735-745.

Yoneyama M, Suhara W, Fukuhara Y, Fukuda M, Nishida E, Fujita T. 1998. Direct triggering of the type I interferon system by virus infection: Activation of a transcription factor complex containing IRF-3 and CBP/p300. EMBO J 17: 10871095.

Yoneyama M, Kikuchi M, Natsukawa T, Shinobu N, Imaizumi T, Miyagishi M, Taira K, Akira S, Fujita T. 2004. The RNA helicase RIG-I has an essential function in double-stranded RNA-induced innate antiviral responses. Nat Immunol 5: $730-737$.

Yoneyama M, Kikuchi M, Matsumoto K, Imaizumi T, Miyagishi M, Taira K, Foy E, Loo YM, Gale M Jr, Akira S, et al. 2005. Shared and unique functions of the DExD/H-box helicases RIG-I, MDA5, and LGP2 in antiviral innate immunity. J Immunol 175: 2851-2858.

Zhang SY, Jouanguy E, Ugolini S, Smahi A, Elain G, Romero P, Segal D, Sancho-Shimizu V, Lorenzo L, Puel A, et al. 2007. TLR3 deficiency in patients with herpes simplex encephalitis. Science 317: 1522-1527.

Zhao J, Kong HJ, Li H, Huang B, Yang M, Zhu C, Bogunovic M, Zheng F, Mayer L, Ozato K, et al. 2006. IRF-8/interferon (IFN) consensus sequence-binding protein is involved in Toll-like receptor (TLR) signaling and contributes to the cross-talk between TLR and IFN- $\gamma$ signaling pathways. $J$ Biol Chem 281: 10073-10080.

Zhong B, Yang Y, Li S, Wang YY, Li Y, Diao F, Lei C, He X, Zhang L, Tien P, et al. 2008. The adaptor protein MITA links virus-sensing receptors to IRF3 transcription factor activation. Immunity 29: 538-550. 


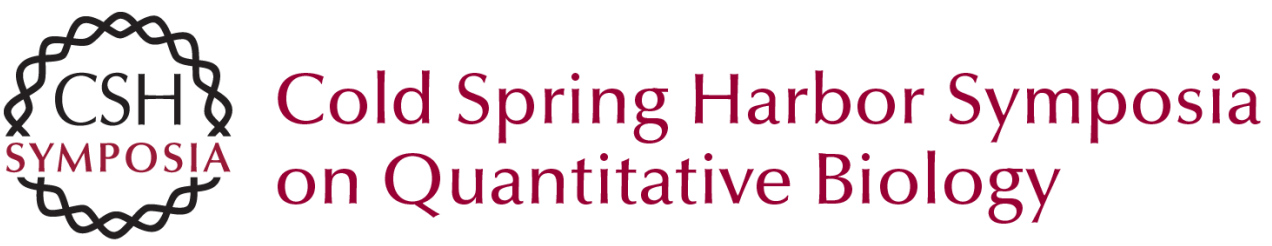

\section{The IRF Family Transcription Factors at the Interface of Innate and Adaptive Immune Responses}

Hiroaki Ikushima, Hideo Negishi and Tadatsugu Taniguchi

Cold Spring Harb Symp Quant Biol 2013 78: 105-116 originally published online October 3, 2013 Access the most recent version at doi:10.1101/sqb.2013.78.020321

References This article cites 116 articles, 39 of which can be accessed free at: http://symposium.cshlp.org/content/78/105.full.html\#ref-list-1

License

Email Alerting Receive free email alerts when new articles cite this article - sign up in Service the box at the top right corner of the article or click here. 